\title{
BUSINESS MODEL TRANSFORMATION - CHALLENGES FOR THE MANAGEMENT OF THE HEALTH CARE ENTITY
}

\author{
Aleksandra Szewieczek ${ }^{1, a, *}$ \\ ${ }^{1}$ University of Economics in Katowice, Department of Accounting, ul. Bogucicka 3, 40-257 Katowice, \\ Poland \\ aaleksandra.szewieczek@ue.katowice.pl \\ *Corresponding author
}

Cite as: SZEWIECZEK, A. (2019). Business model transformation - challenges for the management of the health care entity. Ekonomicko-manazerske spektrum, 13(2), 46-55.

Available at: dx.doi.org/10.26552/ems.2019.2.46-55

\begin{abstract}
Every organisation has shaped its business model, which defines the way of creating value. Obviously, there several incentives for development as well as factors limiting the modification of business models. They can concern various sectors and also be analysed in various information sections. When looking for the determinants of shaping business models, one should carry out their classification. Conducting medical activity takes place in a special environment and the creation of business models in a health organisation requires close attention. Financing health care is predominantly made from public funds. As a result, shaping the revenue stream is significantly limited, as well as its differentiation. In turn, in terms of costs, unfavourable phenomena occur, causing their growth. Healthcare services are provided under quite special circumstances. Among other phenomena, one can perceive the movement of human resources from less wealthy economies to those offering more favourable employment conditions. It is also possible to identify determinants resulting mainly from the law regulation, as well as located in the field of behavioural, cultural and social factors. The phenomena mentioned above results in the transition of the business model of medical activity. These effects are also noticeable in financial flows of costs and revenues, as well as in cash flows. All of the mentioned above phenomena are important for managers who tend to pursue the set goals. In some situations, it is advisable to change the way the organization operates, to shape its organizational structure and network of connections with the environment. The aim of the article is to identify and classify barriers and incentives of business model transformation in health care organizations. The hypothesis states that among the determinants of business model transformation in health care organization tax optimization and limited resources availability are very important for their managers. The research methods contain meta-analysis of literature, observation, case-study and cause and effect relationship analysis as well as the method of synthesis.
\end{abstract}

Keywords: business model, health care, hospital, transformation, finance

JEL Classification: I19, M21, M41 


\section{Introduction}

The dynamic nature of the environment, changing economic conditions and the state's health policy objectives pose particular challenges to health care entities. One of the most acute problems is obtaining sources of financing to cover the costs of health services. The availability of these sources and their wealth is particularly strongly moulded by health policy and the state of the economy (Turcotte-Tremblay et al. 2016; Nghiem and Connelly, 2018; Wagstaff et al. 2018). Another important problem is the acquisition and management of other resources, including mainly human resources and technical infrastructure, especially of a specialized nature. The processes of managing limited resources in health care attract the attention of many scientists from various fields (Vissers, 1995; Ottolini et al., 2016). As a result of the impact of the indicated phenomena, as well as many others, the organizational forms of medical activity are undergoing a transformation, as well as their strategy, market orientation and product orientation.

\subsection{Literature review}

The business model (b.m.) as a separate expression appears in the scientific literature in the mid-1950s (Osterwalder et al., 2005). The interests of researchers intensified in the 1990s and have been continuing to develop. The concept of the business model in the literature is very scattered. There are a lot of various definitions and multi-criteria classifications. Despite various definitional approaches, it is important to emphasize the process character of the business model concept and its focus on the value creation process. The business model provides an architecture for the product, service and information flows, including a description of various business actors and their roles, and the description of potential benefits for those various actors and a description of the sources of revenues (Timmers, 1998). As stressed by Fielt (2014), the business model is the logic of the organization's value from the perspective of creating and capturing customer values. It is presented as a set of related elements concerning the dimensions: customer, value creation, entity's organisation and the economic dimension. The financial dimension of b.m. concept is emphasized in turn by Clark et al. (2013), indicating that the business model is the way in which the organization secures its financial survival. The financial perspective of this concept is also stressed by the definition of the International Integrated Reporting Council, indicating that it is the organization's chosen system of transforming inputs, through its business activities, into outputs and outcomes that aims to fulfill the organization's strategic purposes and create value over the short, medium and long term (IIRC, 2013).

The business model concept is related to the processes of innovation diffusion. Initially, this concept was associated with the transformation of traditional commercial activities to those related to e-commerce. Gradually, however, it began to expand into other industries or areas of activity, including, for example, the sector of small and medium-sized enterprises, high-tech mobile services, material efficiency services (Cavalcante et al., 2011). Studies on b.m. concept are also conducted in the field of adapting business models of incumbent organizations after their disruptions and how these organizations change strategies to cope with new challenges resulting from the changes in the environment (Cozzolino et al., 2018; Snihur et al., 2018). The business model concept is also studied simultaneously with the topic of disruptive innovation (Christensen et al., 2018; Kumaraswamy et al., 2018).

Currently, the concept of the business model is broadly reflected, not only in the aspect of innovation, organisational changes, searching for sources of development. It is also treated as a form of presentation of value creation sources and processes in an enterprise, addressed to 
external stakeholders (ICAEW, 2010; Disle et al. 2016; Lassini et al., 2015). The reflection of the business model in non-financial reporting of companies is an expression of this fact. IASB and IIRC decided that corporate reporting should evolve towards communication about the business model and value creation, which should be reflected in the Integrated Report (IIRC 2013).

This is indicated by broadening researchers' interests also to its mapping in healthcare organisations (Castano, 2014; Hwang and Christensen, 2008; Szewieczek, 2017). The review of paper databases contained in scientific journals (peer-reviewed) was conducted in a view to find the expressions 'business model' and 'health care' in the publication (publication 1) or only in the title of the publication (publication 2). The examination allows to notice that it is only in the last decades, research has touched on this subject to a greater extent, although they are few (Table 1).

Table 1: Databases searching results for the expressions: „, business model“ and „, health care“

\begin{tabular}{|c|c|c|c|}
\hline $\begin{array}{l}\text { The database } \\
\text { name }\end{array}$ & Publication (1) & Publication (2) & Additional information \\
\hline ProQuest & $\begin{array}{l}1992 \text { (Nordin, 1992) - research on } \\
\text { alternate site health care (ASHC) }\end{array}$ & $\begin{array}{l}2008 \text { (Hwang, } \\
\text { Christensen, 2008) }\end{array}$ & $\begin{array}{l}\text { Changing the search phrase } \\
\text { by replacing "health care" }\end{array}$ \\
\hline EBSCOhost & $\begin{array}{l}1985 \text { (Miaoulis et al., 1985) - research } \\
\text { on b.m. for hospital marketing decision- } \\
\text { making processes and relationships }\end{array}$ & $\begin{array}{l}2008 \text { (Hwang, } \\
\text { Christensen, 2008) }\end{array}$ & $\begin{array}{l}\text { with the phrase } \\
\text { "healthcare" or only } \\
\text { "health" included in the title }\end{array}$ \\
\hline Scopus & $\begin{array}{l}1979 \text { (Consler, 1979) - research on } \\
\text { decision-making process in the field of } \\
\text { capital expenditure against the } \\
\text { background of five stages of the b.m. }\end{array}$ & $\begin{array}{l}1997 \text { (Westra, } \\
\text { Boylan, 1997) }\end{array}$ & $\begin{array}{l}\text { of the publication does not } \\
\text { significantly broaden the } \\
\text { search results. The list of } \\
\text { publications only increases }\end{array}$ \\
\hline ScienceDirect & $\begin{array}{l}1995 \text { (articles related to business } \\
\text { process reengineering). Articles more } \\
\text { connected with business models } \\
\text { problems occur in } 1996 .\end{array}$ & $\begin{array}{l}1997 \text { (Watson, } \\
\text { 1997) }\end{array}$ & $\begin{array}{l}\text { to a maximum of } 31 \\
\text { (Scopus), but } \\
\text { simultaneously the earliest } \\
\text { year of publication is } 1999\end{array}$ \\
\hline
\end{tabular}

Source: own study based on the contents of the indicated database .

Studies on the b.m. in health care are scarce in Poland. They have been conducted so far, only in selected areas mainly by A. Jabłoński and M. Jabłoński (2013), Ostrowska (2013), Jaworzyńska (2014, 2015), and recently Szewieczek (2017). Meanwhile, emphasizing the process-oriented character of the business model and the process-oriented nature of the medical activity as well as significant turbulence of the conditions of its conduct, it is advisable to use this concept in the management of health care entities.

Developing and changing the business model in health care has multiple causes. In addition to traditional indicators related to the impact of organisational, financial, or functional factors, it is possible to point to innovative activities. Business model innovation can be perceived as "discovery of a fundamentally different business model in an existing business" (Markides, 2006), it generally means that an organization is searching for new business processes, new ways of creating and capturing value for different stakeholders (Casadesus-Masanell, Zhu, 2013). Innovations of business models in health care mainly concern areas related to the socalled digitalization, e-health and telemedicine (Garrety et al., 2014; Jog et al. 2015). In addition, innovations may also concern the extension of health care for the elderly, as well as the modification of the business model in the field of regenerative medicine (Banda et al., 2018). Another problem for taking managerial decisions is information asymmetry as the lack of perfect information (Bergh et al. 2019). The initiative to change business models in health care is also a financial issue. Cooper et al. (2018) indicated that in concentrated insurer markets hospitals can set lower prices and bear more financial risks. As a result, it is reflected in merging 
hospitals. Changing the business model may be also connected with the fact that diversification may be the way to provide additional market opportunities for enterprises that are constrained by small domestic markets (Schommer et al., 2018). This is particularly relevant for small forprofit hospitals.

In the search for the determinants of changes in business models in health care, it is necessary to examine the grounds and scope of systemic changes in health care, as well as in other sectors or areas of the economy that affect it. Undoubtedly, the strong dependence of this system on political decisions as well as cultural and economic influences determines inference. The power of influence and the position of these determinants may be different under specific political, economic and cultural conditions of the health care system. The shaping of business models of healthcare settings is also subject to the indicated impacts. Although, apart from the implementation of financial objectives in health care, the goal of satisfying social needs comes to the fore.

\section{Methodology}

The research goal of the study is to identify and classify barriers and incentives of business model transformation in health care organizations. The tested hypothesis states that among the determinants of business model transformation in health care organization tax optimization and limited resources availability are very important for their managers.

The analysis of the literature in the field of business model theories and aspects of the health care providers functioning as well as presentation of their environmental (mainly economics) conditions of functioning, conducted in the form of meta-analysis, was the starting point for the observation and assessment of the reasons for health providers' business model transition. The studies on the determinants as well as barriers and incentives of business model transformation were conducted in two companies. The first is a commercial hospital with a smaller scale of activities, although providing a variety of inpatient and outpatient services. The hospital has got 51 beds on 5 wards, as well as facilities of operating theatres and diagnostic imaging laboratories. The second is a capital company providing infrastructure for the hospital (property and movables). These two companies operate on polish health care market and represent polish capital.

The study was conducted in the following part by the method of observation and case study, as well as interviews with management staff to validate the hypothesis. The cause and effect relationship analysis was also carried out.

\section{Results}

Grouping the determinants of business models' transformation of healthcare units, the presented classification is based on the business model components indicated by Bossidy and Charan (2008). This approach divides the determinants into three groups: external conditions, internal conditions and financial goals (Table 2). At the same time, it should be emphasized that it is possible to decompose them from the perspective of setting incentives or barriers for health entities' business model transition.

Table 2: Determinants of business model transition in healthcare units

\begin{tabular}{lll}
\hline $\begin{array}{l}\text { External conditions' } \\
\text { determinants }\end{array}$ & Financial goals & $\begin{array}{l}\text { Internal conditions' } \\
\text { determinants }\end{array}$ \\
\hline $\begin{array}{l}\text { Health policy provided by the } \\
\text { central and local Government }\end{array}$ & Improving value for the owners & Ownership structure
\end{tabular}


Business model transformation challenges

for the management of the health care entity

Author: Aleksandra Szewieczek

Economic development

Patients' health status - customer

base

Dependency on local government

Resource availability

Company location

Health care funding rules
Tax optimization

Achieving/maximizing financial surplus

Asset structure composition

Cash flow composition

Owner's equity compostition

Proper medical procedures valuation

\author{
Strategy \\ Organizational structure \\ Operational activities flows \\ Employee engagement \\ Activities specialization \\ Relationships with contractors
}

Source: own study based on Bossidy and Charan (2008).

The determinants indicated in the above table have not been classified considering their weight. The significance of the determinants depends on the characteristics of the operation of each specific health care market. Clearly, at the very top of external determinants, there is a state healthcare policy that creates a specific framework for the functioning of healthcare entities (Horgan et al., 2018; Sakellariou and Rotarou, 2017), as well as a closely related policy of financing healthcare services from public funds (Ataguba et al., 2018; McCoy et al., 2017; Yates, 2015). The place of service provision is equally important, which determines the availability of resources and their costs, as well as in some cases the demand for healthcare services (Guagliardo et al., 2004; Marino and Quattrone, 2018).

The ranking of financial goals will, in turn, determine the ownership structure of the entity. In the case of public sector entities, the dominant position will be taken by the appropriate structure of assets and liabilities, and on the other hand, in private sector entities, the maximisation of benefits for the owners comes to the forefront.

In complex organisational structures, the striving to change and the effects of introduced changes are much more likely to be visible. Such units, having appropriate facilities, are able to initiate and implement changes. In turn, the liquidity of implementation in smaller units, due to the smaller implementation scope, can be faster.

Resource allocation is another important managerial issue for managing health care entities. It is crucial for obtaining financial and non-financial goals in an organization (Bower, 2017).

The work of people is one of the most important resources in the healthcare sector. The movement of these resources from less affluent countries to those offering more favourable employment conditions is observable. Poland is indicated in this area to be an unusual country of the EU. It is rather a source country than a destination one, although it has a complex healthcare system. For example, in the years 2003-2005 Polish doctors were the 6th largest migration group in health care in the United Kingdom. The main reason for the migration is low salaries, especially for young medical doctors and mid-level health personnel (Siyam and Dal Poz, 2014). These processes also affect medical students in Poland who see emigration as an important alternative to career development (Krajewski-Siuda et al., 2012). Thus, it intensifies the brain-drain phenomenon, which is particularly severe for the economy from the perspective of the availability of highly-skilled workers (Hejdukova and Kurekova, 2016; Krajewski-Siuda and Romianuk, 2007).

There is also a movement of specialized hospital infrastructure services between countries, for example, maintenance of medical devices, which market is quite hermetic. It should also be added that the medical equipment resource is important for the quality of therapeutic processes (Wahed et al., 2010). Integration of all activities related to medical activities can be an important step to reorient the management of the entity. Such specialization, close links with the conducted activity is the starting point for introducing a balanced approach and focusing on quality and effectiveness as well as optimization of medical activities (Kuebler, 2017). 
The examined hospital (Entity A) conducts activities focused on health care. The property in which the activity is conducted belongs to another entity (Entity B), not directly affiliated but stays in a strict personal dependency on part of the owners and the management of Entity A. Specialist and general movable property (fixed assets) is also provided by this entity (B). Simultaneously, the hospital also acquires medical devices on its own account.

The management of both companies, considering mainly their economic situation, began a discussion on changing the business model of both entities. The following reasons were indicated:

- A relatively worse balance-of-payments situation of Entity B (negative cash flow balance) and improving the financial position of Entity A.

- Imbalance in accounting for VAT due to rent: Entity A, in relation to the type of business activity, does not deduct VAT charged on the rent and recognizes it as a cost. Entity B shows VAT on rent services in large part as a tax liability.

- Terms and conditions of loan agreements for the purchase of rented infrastructure by Entity B.

- Operational difficulties in accounting for current infrastructure transactions (mistakes in documentation between entities A and B).

- Striving to focus on current processes related to medical activity in Entity A, in order to improve the quality of therapeutic processes and patient satisfaction (MioduchowskaJaroszewicz and Romanowska, 2016).

The change in the business model under consideration would consist in separating two clearly distinguished areas of activity within Entity B activity (lease of property and rental of medical movable property) and transferring the other one to Entity A as a contribution of an organized part of the enterprise. Consideration was also given to the option of selling part of the infrastructure or donation. Conducting further exploratory activities, a list of barriers and incentives to change the business model was prepared (Table 3).

Table 3: Barriers and incentives of business model transition in the selected companies

\begin{tabular}{|c|c|c|}
\hline Barriers & Determinants & Incentives \\
\hline $\begin{array}{l}\text { Terms and conditions of loan agreements } \\
\text { concluded by Entity B }\end{array}$ & \multirow{3}{*}{ External conditions } & $\begin{array}{l}\text { Existing tax regulations entailing tax } \\
\text { advantages for in-kind contribution of an } \\
\text { organized part of Entity A to Entity }\end{array}$ \\
\hline $\begin{array}{l}\text { Tax risk of different treatment of } \\
\text { transactions by tax authorities }\end{array}$ & & $\begin{array}{l}\text { Ownership structure of Entities A and B } \\
\text { and family relations among owners }\end{array}$ \\
\hline $\begin{array}{l}\text { Conditions for financing health services } \\
\text { from public funds }\end{array}$ & & $\begin{array}{l}\text { its payer, whereas Entity A cannot settle } \\
\text { it because it provides services exempt } \\
\text { from VAT }\end{array}$ \\
\hline $\begin{array}{l}\text { The need to reorganize the operations of } \\
\text { Entity B by distinguishing two areas of } \\
\text { activity }\end{array}$ & \multirow{3}{*}{ Internal conditions } & $\begin{array}{l}\text { Improvement of medical equipment } \\
\text { management by a direct user (Entity A) }\end{array}$ \\
\hline $\begin{array}{l}\text { Changes in the content of commercial } \\
\text { contracts concluded by Entity B with sub- } \\
\text { tenants }\end{array}$ & & $\begin{array}{l}\text { Concentration of assets related to } \\
\text { medical activities in one entity (A) }\end{array}$ \\
\hline $\begin{array}{l}\text { Introduction of the organizational rules in } \\
\text { Entity B, the need to modify the } \\
\text { accounting }\end{array}$ & & $\begin{array}{l}\text { Limitation of errors in settling } \\
\text { transactions with contractors (mistakes in } \\
\text { identifying transactional parties between } \\
\text { entities A and B) }\end{array}$ \\
\hline $\begin{array}{l}\text { Loss of revenue proportion with a } \\
\text { relatively lower rate of decline in the costs } \\
\text { of Entity B }\end{array}$ & Financial goals & $\begin{array}{l}\text { The improvement of the financial result } \\
\text { mainly in Entity B }\end{array}$ \\
\hline
\end{tabular}


Increasing income taxes in Entity A

(lower lease costs)

The risk of difficulties in repaying longterm debt in Entity B
Improvement of cash flows

Reduction of tax liabilities due to VAT tax in Entity B

Source: own study Bossidy, L. \& Charan, R. (2008). Szósty zmyst w zarządzaniu firma. Tworzenie planówi modeli biznesowych. Warszawa, Poland: Wydawnictwo MT Biznes.

As a result of the analysis of the above-mentioned factors, the decision was made to change the business model in the examined entities.

\section{Discussion}

Among the identified incentives and barriers, in the interviews conducted with the management of Entities A and B, the arguments for the possibility of reducing VAT tax liabilities and disposal of these amounts for the repayment of investment loans taken out for the hospital construction came to the fore. Such a stance was strongly influenced by the tax law allowing tax-neutral transfer of the organized part of enterprise B to Entity A. Following this transfer, Entity A was also to take over all rights and obligations related to the acquired scope, including service, insurance and guarantee contracts as well as a loan financing the purchase of a part of the in-kind contribution. A positive effect was also indicated in terms of concentrating processes related to medical activity in one entity, which facilitates focusing on the appropriate course of treatment processes and their quality. Due to the ongoing process, only a model representation of described changes is possible (Figure 1).

Figure 1: The effects of business model transition in Company A and B
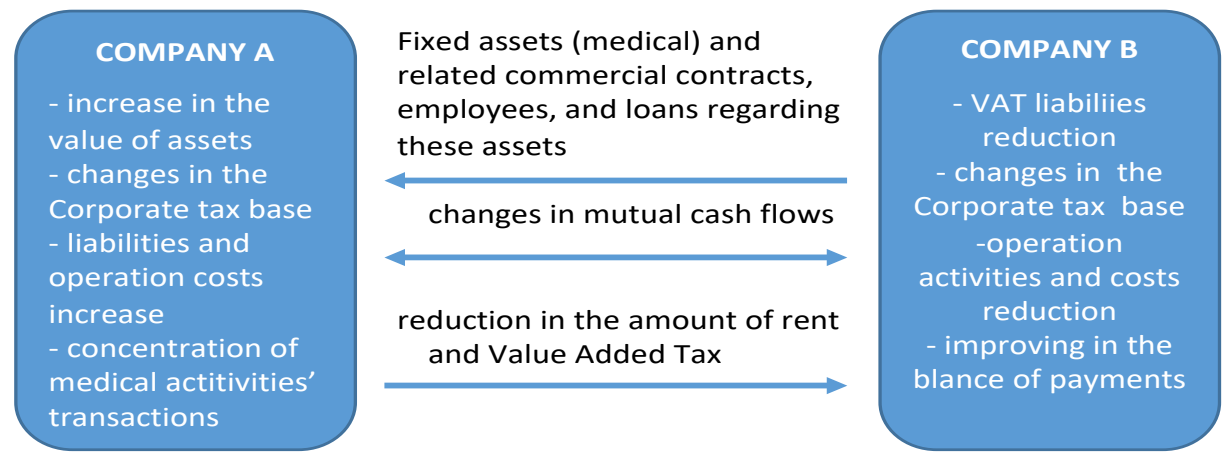

Source: own study based on companies source data

The indirect effect of the changes introduced in the b.m. will be the improvement of the quality of the cost valuation of the medical procedures performed. This will be due to the full inclusion of the costs of medical equipment in Entity A (Nascimento et al., 2007).

The business model transition process in the indicated entities is still ongoing. It requires the performance of several formal activities (tax authorities' interpretation, organizational regulations, new accounting principles, inventory and asset valuation, attestation of the in-kind contribution valuation by an auditor, obtaining consents from the funding bodies and the lender). What follows from this, the full financial effect of the introduced modification of the business model in both units will be known only after about a year from the implementation of all indicated changes. 


\section{Conclusion}

The business model transformation made both entities seek, first and foremost, a financial effect, while the priority was the situation of Entity B. As a result, Entity B not only reduced costs and revenue and tax liabilities but also its scale of operations. The terms of lease contracts were significantly reduced and a number of business transactions resulted from them. At the same time, the position of Entity A was strengthened from the perspective of the ability to control the quality of treatment processes (supervision over medical equipment). On the other hand, the main premise was to obtain benefits in cash flows between Entity B and A as well as tax advantages. The possibility of free settlement of other amounts, of course within legally acceptable limits, between the examined entities is also significant.

Conducted research, based on the example of both entities, allowed to verify positively the hypothesis that among the determinants of business model transition in health care organization tax optimization and limited resources availability are very important. It can also be concluded that the financial effect of changing the business model is determined not only by the terms of business and tax law, but mainly by the internal conditions of the entity: its relations with the environment, implemented strategy and adopted operational goals (including financial ones). In addition, the activities carried out in the examined case involve a tax risk that may arise as a result of questioning the settlement of the transaction by the tax authorities. The final financial and operational effect will be known after about a year of functioning of the fully implemented changes.

Due to the nature of the conducted research and the applied method, the basic limitations of the study are a significantly limited research sample and a possible subjective character of the results of the conducted interviews. An important factor that can differentiate the results of research is also the occurrence of family connections between the owners of the surveyed entities, as well as the study concerns a private hospital. In non-profit hospitals, the governance system may differ fundamentally (Adelino et al., 2014). These limitations, however, do not affect, in the opinion of the authors, the possibility of formulating general conclusions that have been indicated above. They provide the background for further in-depth research into business model transformation in health care.

\section{References}

Bossidy, L. \& Charan, R. (2008). Szósty zmyst w zarządzaniu firmą. Tworzenie planów i modeli biznesowych. Warszawa, Poland: Wydawnictwo MT Biznes.

Clark, T., Osterwalder A. \& Pigneur Y. (2013). Model biznesowy Ty. Gliwice, Poland: Helion.

Siyam, A. \& Dal Poz, M. R. (eds.). (2014). Migration of health-care workers: WHO code of practice and the global economic crisis. Geneva: World Health Organization.

Adelino, M., Lewellen, K. \& Sundaram, A. (2014). Investment decisions of nonprofit firms: Evidence from hospitals. The Journal of Finance, 70(4), 1583-1628.

Ataguba, J.E., Asante, A.D., Limwattananon S. \& Wiseman, V. (2018). How to do (or not to do) ... a health financing incidence analysis. Health Policy and Planning, 33(1), 436-444.

Banda, G., Tait, J. \& Mittra, J. (2018), Evolution of business models in regenerative medicine: Effects of a disruptive innovation on the innovation ecosystem. Clinical Therapeutics, 40(7), 1084-1094.

Bergh, D.D., Ketchen, Jr., D.J., Orlandi, I., Heugens. P.P.M.A.R. \& Boyd, B.K. (2019). Information asymmetry in management research: Past accomplishments and future opportunities. Journal of Management, 45(1), 122158.

Bower, J.L. (2017). Managing resource allocation: Personal reflections from a managerial perspective. Journal of Management, 43(8), 2421-2429.

Casadesus-Masanell, R. \& Zhu, F. (2013). Business model innovation and competitive imitation: The case of sponsor-based business models. Strategic Management Journal, 34(4), 464-482. 
Cavalcante, S., Kesting, P. \& Ulhøi, J. (2011). Business model dynamics and innovation: re(establishing) the missing linkages. Management Decision, 49(8), pp. 1327-1342.

Christensen, Ch.M., McDonald, R., Altman, E.J. \& Palmer, J.E. (2018). Disruptive innovation: An intellectual history and directions for future research. Journal of Management Studies, 55(7), 1043-1078.

Consler, J.E. (1979). The capital expenditure process in short-term, voluntary non-profit community hospitals in the state of Minnesota. Abstracts of Health Care Management Studies, 16(1), 21250.

Cooper, Z., Craig, S.V., Gaynor, M. \& Reenen, J.V. (2018). The price ain't right? Hospital prices and health spending on the privately insured. The Quarterly Journal of Economics, 134(1), 51-107.

Cozzolino, A., Verona, G. \& Rothaermel, F.T. (2018). Unpacking the disruption process: New technology, business models, and incumbent adaptation. The Journal of Management Studies, 55(7), 166-1202.

Disle, Ch., Perier, S., Bertrand, F., Gonthier-Besacier, N. \& Protin, Ph., R. (2016), The business model concept and accounting standard setting: How has the concept been integrated into the IFRS framework?. Comptabilite Controle Audit, 22(1), 85-119.

Fielt, E. (2014). Conceptualising business models: Definitions, frameworks and classifications. Journal of Business Models, 1(1), 85-105.

Garrety, K., McLoughlin, I. \& Zelle, G. (2014). Disruptive innovation in health care: business models, moral orders and electronic records. Social Policy \& Society, 13(4), 579-592.

Hejdukova, P. \& Kurekova, L. (2016). The globalized world an migrants: Impacts on healthcare markets. Proceedings of the $16^{\text {th }}$ International Scientific Conference Globalization and its Socio-Economics Consequences, Rajecke Teplice, Slovak Republic: 628-635.

Hwang, J. \& Christensen, C.M. (2008). Disruptive innovation in health care delivery: A framework for businessmodel innovation. Health Affairs, 27(5), 1329-1335.

ICAEW, (2010). Business model in accounting: The theory of the firm and financial reporting. London: ICAEW.

IIRC, International Accounting Standards Board \& International Integrated Reporting Council (2013), Memorandum of understanding, Integrated Corporate Reporting Framework. Retrieved from www.ifrs.org.

Jabłoński, A. \& Jabłoński, M. (2013). Jak w praktyce budowac modele biznesu i strategii dla jednostek opieki zdrowotnej. Controlling i Rachunkowosc Zarzaddcza, 10.

Jaworzyńska, M. (2015). Analiza strategiczna zakładu opieki zdrowotnej na potrzeby stworzenia jego modelu biznesowego - studium przypadku. Research Papers of Wroclaw University of Economics, 399,196-207.

Jaworzyńska, M. (2014). Powiązanie modeli biznesowych z zarządzaniem strategicznym w zakładzie opieki zdrowotnej. Research Papers of Wroclaw University of Economics, 343, 192-201.

Jog, Y., Sharma, A., Mhatre, K. \& Abhishek., A. (2015). Business approach for IoT based health solutions in India with respect to osterwalder framework. International Journal of Bio-Science and Bio-Technology, 7(6), 173188.

Krajewski-Siuda, K., Szromek, A., Romaniuk, P., Gericke C. A., Szpak, A. \& Kamczarek, K. (2012). Emigration preferences and plans among medical students in Poland. Human Resources for Health, 10(8).

Krajewski-Siuda, K. \& Romaniuk, P. (2007). Health worker emigration from Poland. Journal of Public Health Policy, 28(2), 290-292.

Kuebler, W.F. (2017). Efficiency in the hospital: A matter of course, reality and challenge. Therapeutische Umschau, 74(1), 796-804.

Kumaraswamy, A., Garud, R. \& Ansari, S. (2018). Perspectives on disruptive innovations. Journal of Management Studies, 55(7), 1025-1042.

Lassini, U., Lionzo, A. \& Rossignoli, F. (2015). Does business model affect accounting choices? An empirical analysis of European listed companies. Journal of Management \& Governance, 20(2), 229-260.

Markides, C. (2006). Disruptive innovation: In need of better theory. Journal of Product Innovation Management, 23(1), 19-25.

McCoy D., Chigudu, S. \& Tillmann, T. (2017). Framing the tax and health nexus: A neglected aspect of public health concern. Health Economics, Policy and Law, 2(2), 179-194.

Miaoulis, G., Anderson, D.C., LaPlaca, P.J., Geduldig, J.P., Gleeler, R.H. \& West, S. (1985). A model for hospital marketing decision processes and relationships. Journal of Health Care Marketing, 5(2), 37-45.

Mioduchowska-Jaroszewicz, E. \& Romanowska, M. (2016). Profitability evalutation of hospital departments forming a health care entity. Economics and Sociology, 9(3), 224-232.

Nascimento, L.N., Calil1, S.J. \& Hermini A.H. (2007). Custo dos Equipamentos Eletromédicos nos Procedimentos de Assistência à Saúde (Electromedical equipment costs in health care procedures). In: Müller-Karger, C., Wong, S. and La Cruz A. (eds). IV Latin American Congress on Biomedical Engineering 2007, Bioengineering Solutions for Latin America Health. IFMBE Proceedings, 18, 843-846.

Nordin, J.R. (1992). Systems implications of alternative site healthcare. Journal of Systems Management, 43(6), 13-41. 
Ostrowska, S. (2013). Strategiczne zarządzanie wynikami a modelowanie przyszłych decyzji organizacji publicznej. Research Papers of Wroclaw University of Economics, 277, 89-100.

Ottolini, F.L., Buggio, L., Somigliana, E. \& Vercellini, P. (2016). The complex interface between economy and healthcare: An intoductory overivew for clinicians. European Journal of Internal Medicine, 36, pp. 1-6.

Sakellariou, D. \& Rotarou, E.S. (2017). The effects of neoliberal policies on access to healthcare for people with disabilities. International Journal for Equity in Health, 16(1), 199.

Schommer, M., Richter, A. \& Karna, A. (2019). Does the diversification-firm performance relationship change over time? A meta-analytical review. Journal of Management Studies, 56(1), 270-298.

Snihur, Y., Thomas, L.D.W. \& Burgelman, R.A. (2018). An ecosystem-level process model of business model disruption: the disruptor's gambit. Journal of Management Studies, 55(5), 1278-1316.

Szewieczek, A. (2017). Selected problems of cost allocation in hospital - relationship between business model and cost structure. Proceedings of the 17th International Scientific Conference Globalization and Its SocioEconomic Consequences. Proceedings, Rajecke Teplice, Slovak Republic, 2610-2617.

Timmers, P. (1998). Business models for electronic markets. Electronic Markets, 8(2), 3-8.

Watson, Ch.B. (1997). Managed care and the anesthesiologist's role in critical resource management. Anesthesiology Clinics of North America, 15(4), 915-936.

Wagstaff, A., Flores, G., Hsu, J., Smitz, M.-F., Chepynoga, K., Buisman, L. R. \& van Wilgenburg, K., Eozenou, P. (2018). Progress on catastrophic health spending in 133 countries: A retrospective observational study. The Lancet Global Health, 6(2), e169-e179.

Westra, R. \& Boylan, C. (1997). Rapid cycle change: business models can be successful in health care. Aspen's Advisor for Nurse Executives, 12(10), 1-3.

Vissers, J.M.H. (1995). Patient flow based allocation of hospital resources. IMA Journal of Mathematics applied in Medicine and Biology, 12(3-4), 259-274.

Yates, R. (2015). Universal health coverage: Progressive taxes are key. The Lancet, 386(9990), 227-229.

Castano, R. (2014). Towards a framework for business model innovation in health care delivery in developing countries. BMC Medicine, 12(1), 1-7.

Guagliardo, M.F., Jablonski, K.A., Joseph, J.G. \& Goodman, D.C. (2004). Do pediatric hospitalizations have a unique geography? BMC Health Services Research, 4, 1-9.

Horgan, D., van Kranen, H. J. \& Morre, S. A. (2018). Optimising SME potential in modern healthcare systems: challenges, opportunities and policy recommendations. Public Health Genomics, 21, 1-17.

Marino, D. \& Quattrone, G. (2018). A proposal for a new index to evaluate hospital resource allocation: The case of Italian NHS rationalisation. European Research on Management and Business Economics (article in press).

Nghiem, S.H. \& Connelly, L.B. (2017). Convergence and determinants of health expenditures in OECD countries. Health Economics Review, 7(29), 1-24.

Osterwalder, A., Pigneur, Y. \& Tucci, G.L. (2005). Claryfing Business Models: Origins, Present, and Future of the Concept. Communications of the Association for Information Systems, 16, 1-25.

Turcotte-Tremblay, A.-M., Spagnolo, J., De Allegri, M. \& Ridde, V. (2016). Does performance-based financing increase value for money in low- and middle- income countries? A systematic review. Health Economics Review, 6(30).

Wahed, M.A., Sharawi, A.A. \& Badawi, H.A. (2010). Modeling of medical equipment maintenance in health care facilities to support decision making. Proceedings of the 5th Cairo International Biomedical Engineering Conference (CIBEC 2010). Egypt: 202-205. 